\title{
MODELING OF INVESTMENT RISKS ASSOCIATED WITH CHANGES IN LAND RECLAMATION STATUS OF FIRE-DANGEROUS PEATLANDS IN RYAZAN MESHCHERA
}

\author{
Inna Davydova ${ }^{1}$, Evgeny Davydov ${ }^{2}$, Yuri Mazhaysky ${ }^{1}$ \\ ${ }^{1}$ Ryazan State University named after S.A. Yesenin, Russia; ${ }^{2}$ Dubna State University, Russia \\ i.davidova@rsu.edu.ru,davydov@theor.jinr.ru,mail@mntc.pro
}

\begin{abstract}
European Bank for Reconstruction and Development, within the framework of the Energy and Natural Resources program, invests in regions to irrigate peatlands for the implementation of a large-scale international project "Wetlands and Climate". Similar activities began in Meshchera, a large forest and marsh area in Central Russia, where wildfires often occur in dry summers. However, in these investment projects, environmental and economic risks are not sufficiently taken into account. The proposed new approach is based on modelling the soil cover after implementing measures for flooding fire-hazardous peatlands. This allows us to quantify how flooding affects the risks associated with fires. It also allows finding the most economically effective type of land use after flooding. We carried out numerical simulation of flooding for a separate land plot in Ryazan Meshchera, which showed a twofold reduction in the risks associated with fires, as well as an increase in largescale heterogeneity of the soil cover. This led to the conclusion that for this site the most cost-effective will be investment in projects aimed at narrowly specialized land use.
\end{abstract}

Keywords: environmental management, wetlands restoration, fire risks.

\section{Introduction}

The Wetlands International and the Ministry of Natural Resources and Ecology of the Russian Federation signed a memorandum of understanding on the conservation and rational use of wetlands in Russia. Currently in Russia, within the framework of the International Climate Initiative, the project "Restoration of peatlands in Russia - to prevent fires and mitigate the effects of climate change" is being implemented. The purpose of the project is to prevent forest fires and mitigate the climate. The German Development Bank KfW is funding this project. The project participants are the Wetlands International, the Institute of Forest Science of the Russian Academy of Sciences, the Michael Zukkov Foundation, the Greifswald Institute of Botany and Geoecology, the Ministry of Natural Resources and Ecology of the Russian Federation, the government and administration of some constituent entities of the Russian Federation. Financing of the project in 2017 was increased by 1.5 million euros [1].

Initiators of measures to restore wetlands in the Ryazan region are the Ministry of Natural Resources of the Russian Federation, KfW Bank and the German Embassy in Russia. The Wetlands International calls for the conservation of peatlands to reduce the emission of carbon dioxide due to the mineralization of peat on drained bogs. Given this and other reasons, the organization tries to restore peatlands [2]. One of the ways for restoration of peatlands in the European Union and the Eastern Europe is secondary waterlogging. There are many such studies and they are related to environmental management [3-9].

However, Russian legislation significantly limits the secondary flooding of peatlands due to a decrease in natural rent and adverse social consequences. As a rule, flooding of peatlands is carried out on the lands of specially protected natural areas, where small areas of disturbed peatlands are flooded. For example, in the Ryazan region wetlands are allowed to be restored on the biosphere polygon of the Oka State Natural Biosphere Reserve on an area of 910 hectares. It should be noted that the area of fire-dangerous peat bogs in the Ryazan Meshchera is tens of thousands of hectares.

Technological work on the flooding of peat bogs is carried out using the specialized software complex MIKE FLOOD. This program was developed by DHI Water \& Environment for detailed modeling of flood zones and similar phenomena. Complex modeling solves the problem of determining zones of flooding and drainage of floodplain territories [10]. The MIKE FLOOD was used in the design of peat flooding systems in Ryazan Meshchera [11].

However, the application of the MIKE FLOOD outside the floodplain zones - on most of the territory of the Ryazan Meshchera - is problematic. The main reasons are related to the flat terrain of this territory, the presence of drainless areas, low vertical infiltration of drained reservoir peat bogs, high lateral infiltration of sand and sandy loam around peatlands, a large area of peat bogs on watersheds, considerable desiccation of soil moisture in forest areas. For example, this software DOI: 10.22616/ERDev2018.17.N261 
suggests flooding the lowland bogs with alluvial-marsh peaty soils in the river Pra flood plain that are one of the least flammable [12]. This demonstrates an irrational approach to solving the problem of reducing the fire hazard of peatlands.

In order to assess investment risks, when changing the status of land reclamation with firehazardous peat bogs in Ryazan Meshchera, it is required to develop a new methodical approach. It is necessary to take into account the integral fire risks of soils on land sites, and also to predict changes in the nature of land use after flooding of peatlands.

The purpose of our study is to obtain, even approximate, but quantitative estimates of the change in certain characteristics of lands subject to waterlogging. Namely, we are interested in the percentage change in the types of soils that occur on these lands, as well as the change in the configuration of their distribution. These characteristics largely determine the most preferable type of land use for these sites, as well as the risks associated with fire hazard. The quantitative estimates obtained in our work can be directly used in the future both in calculating the most economically efficient bogging model and in analyzing the economic impact of bogging on the economy of these lands.

\section{Materials and methods}

The study was conducted in the Ryazan part of Meshchera outside the floodplain of the Oka River. It is a wooded lowland with peat bogs, its area is several thousand square kilometers, the relief is flat, absolute heights are less than $125 \mathrm{~m}$, the relative heights are generally less than $5 \mathrm{~m}$ (sometimes $5-10 \mathrm{~m}$ ), the natural erosion network is extremely rare, many drainless areas, drainage network, on the contrary, very dense [13].

It is well known that the soil is a "landscape mirror", because the morphology of the soil reflects local natural features. Therefore, in this study, special attention was paid to the characteristics of the soil cover.A decrease in the altitude of the terrain by 0.5-1 m leads to an increase in the degree of soil hydromorphism (bogging) in Meshchera. With the increase ofhydromorphism, soils replace each other in space in the following order:sod-podzolic soil, sod-podzolic slightly-gleyed soil, sodpodzolicgleyey soil, sod-podzolicgley soil, peaty-podzolic soil, peaty soil.We take this effect into account when predicting the degree of fire hazard of soils.

As it is known, the water regime of the soil depends on the availability of precipitation. Reduction of the moisture content of organogenic upper soil horizons to a level below the moisture of the capillary rupture is a prerequisite for soil dryness and fire hazard.

The data on the water regime of soils in Meschera, received by Zaidelman F. R., were also taken into account [14]. He established the relationship between the precipitation availability of the warm period and the drop in humidity of the upper soil horizon (depending on the soil type) below the moisture level of the capillary rupture. For instance, when the precipitation availability of the warm period is above $17 \%$, then the humidity of the upper soil horizon is less than the moisture level of the capillary rupture for the light brown podzolized soil (sod-podzolic soil), which then becomes firehazardous. At the same time, soils with signs of hydromorphism remain sufficiently moist and not fire-hazardous. With precipitation availability above 30-35\%, the humidity of the upper soil horizon drops below the moisture level of the capillary rupture already for some soils with the signs of hydromorphism(sod-podzolic slightly-gleyed soil and sod-podzolicgleyey soil), and now they also become fire hazard. Just to mention, the precipitationavailability describes the precipitation level that is reached in the appropriate number of years (in percent) in the region. For example, the low value of precipitationavailability corresponds to a high amount of precipitation (the number of years with such or higher precipitation level is small).

Therefore, for the study it was important to assess the availability of atmospheric precipitation fire season in the Ryazan Meshchera [15].Such calculations were carried out using data on atmospheric precipitation for 60 years of observations (1951-2010) during the fire season from April to September (see Fig. 1). The average long-term norm of precipitation in the fire-hazardous period is $328 \mathrm{~mm}$ and corresponds to $50 \%$ of the supply. Taking into account the data on the water regime of soils obtained by Zaydelman [14], sod-podzolic soils are fire-hazardous for 50 years out of 60, sod-podzolic softly gleyed soils - for 42 years out of 60 , sod-podzolicgleyey and gley soils - 12 years out of 60 . In 
addition, according to statistics, about every 15 years there are severe droughts, in which the peatypodzolic and peaty soils become fire-dangerous too.

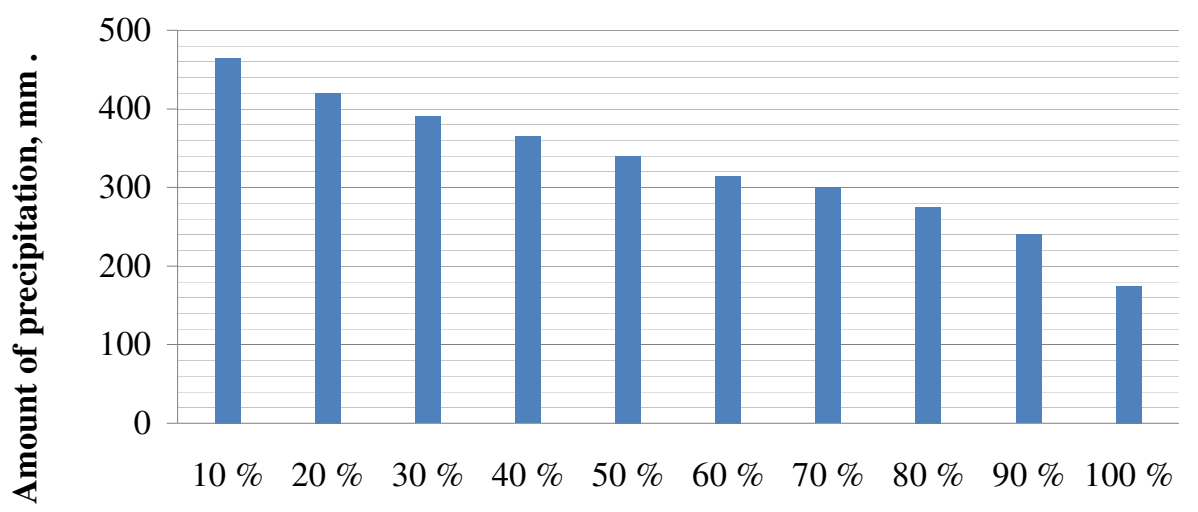

Precipitation availability

\section{Fig. 1. Availability and amount of precipitation in fire season (from April to September)}

To simulate the effects caused by swamping, we chose a typicalRyazanMeshchera site measuring $48 \mathrm{~km}$ by $48 \mathrm{~km}$. For the lands of the Ryazan Meshchera, continuous and smooth changes in all parameters are generally characteristic, therefore the results obtained in the simulation on this site can be extrapolated to a significant part of the Meshchera. The soil map of this section is shown in Fig. 2 . From the viewpoint of fire hazard, it is possible to break down the types of soils into 5 classes: class 0 - meadow-bog soils; class 1 - marsh lowland, transitional and upland peat soils on small and medium peat, peaty and peaty-podzolicgleyey and gley soils; class 2 - sod-podzolicgleyey and gley soils; class 3 - sod-podzolic softly gleyed soils; class 4 - sod-podzolic soils.For convenience, we numbered the classes so that the larger the class number, the higher the fire hazard of these soils.

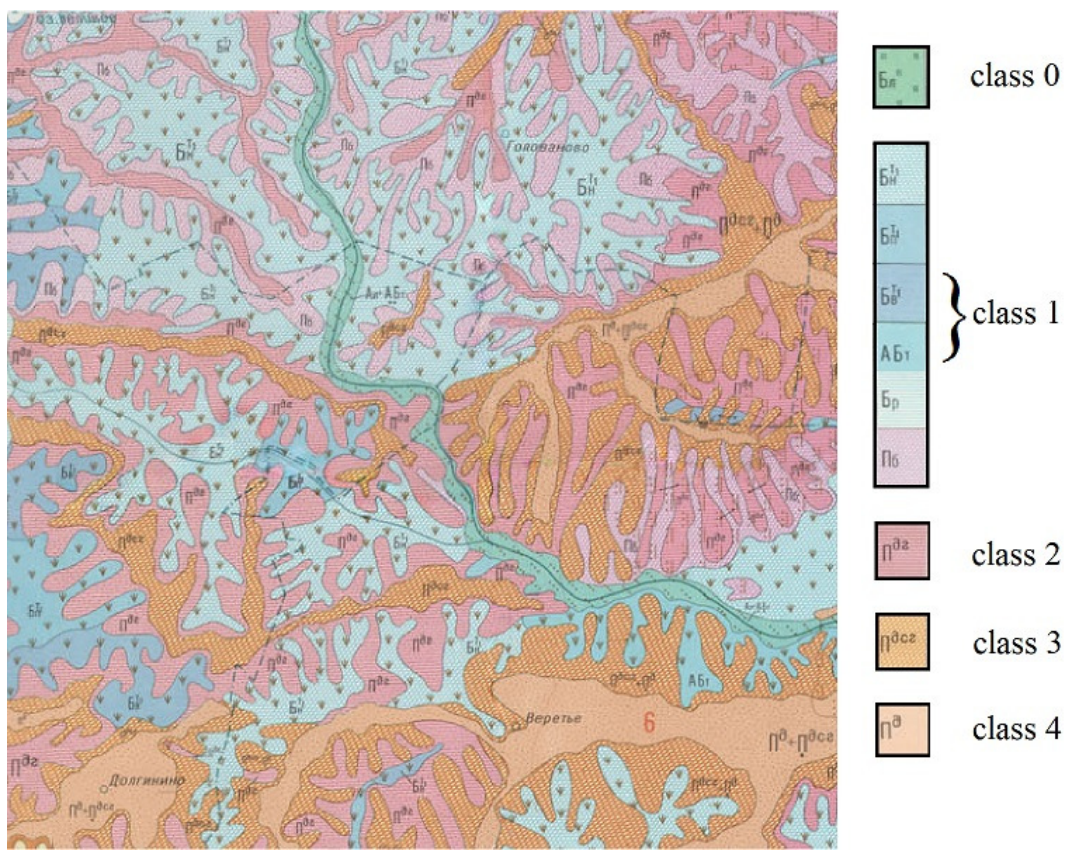

Fig. 2. Soil map of selected site with breakdown of soils by fire hazard classes

The soil map of the selected site is presented in Fig.2. It can be noted that soils of one type form structures with a characteristic scale of $1 \mathrm{~km}$. Therefore, for the purposes of numerical modeling, we presented a soil map in the form of a uniform grid of $48 \times 48$ cells (each cell is a square with a side length of $1 \mathrm{~km}$ ), each of which was assigned one of the soil classes, depending on which soil of the class dominated the site corresponding to this cell. With flooding, the soils of classes 0 and 1 do not change, and soils of classes 2, 3, 4 pass to soils of classes 1,2, 3 respectively. Therefore, the modeling 
of flooding consisted in rebuilding the map with the appropriate replacement of the soil class for each cell. Fig. 3 shows simulated soil maps before and after flooding.

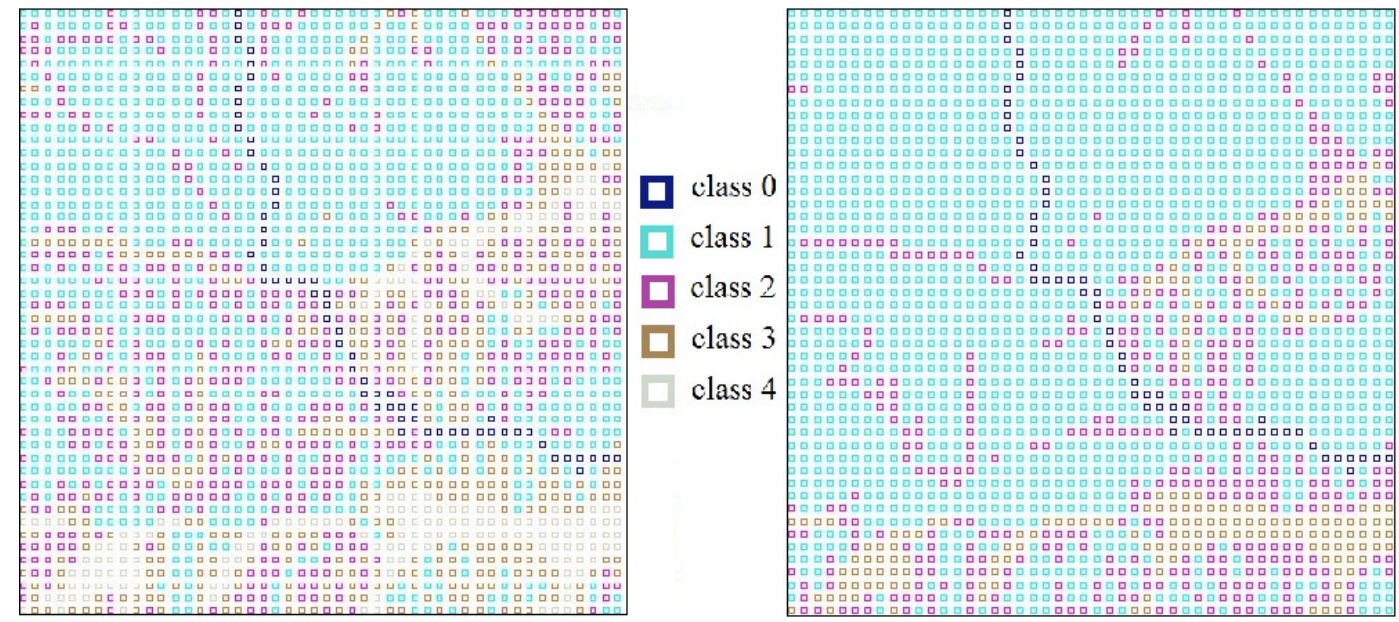

Fig. 3.Simulated soil map of selected site before (on the left) and after (on the right) proposed flooding

Using these simulated maps, it is not difficult to find the areas (as a percentage of the total area of the site) occupied by the soils of each class, before and after flooding. The results are presented in Table 1.

Table 1

Land areas occupied by soils of each class

\begin{tabular}{|c|c|c|c|c|c|}
\hline Flooding state & Class 0 & Class 1 & Class 2 & Class 3 & Class 4 \\
\hline Before flooding & $2.7 \%$ & $46 \%$ & $24 \%$ & $19 \%$ & $8.3 \%$ \\
\hline After flooding & $2.7 \%$ & $70 \%$ & $19 \%$ & $8.3 \%$ & $0 \%$ \\
\hline
\end{tabular}

The fire hazard of soils can be calculated from long-term observations of rainfall and precipitation availability. Let us define the fire risk for each soil class as the ratio of the number of years, when the soils of this class are fire hazardous to the total number of years for the period of observation. According to the data given above, the fire risks of the classes 0 to 4 are $0,0.067,0.2,0.7$ and 0.83 , respectively. The integrated fire risk of the soils of the simulated site can be calculated as the sum of the areas presented in Table 1, taken with weights corresponding to the fire risks for each class. Before flooding, this value is 27.8 , and after -14.1 . The ratio of these values shows that fire risks associated with the soils can be reduced by approximately $50 \%$ after flooding.

However, an important characteristic of a land plot is not only the total area occupied by the soils of each class, but also their distribution over the site. Namely, we can calculate the total length of the boundaries between soils of different classes. That is, if neighboring cells are occupied by soils of one class, then we believe that there is no border between them. And if they are occupied by soils of different classes, we increase the length of the boundary by one (here the unit length corresponds to the size of the cell, i.e., $1 \mathrm{~km}$.). These values for the simulated land plot are $L=1930$ and $L=1160$ before and after flooding. In absolute terms, these numbers are not informative, since they depend on the calculation method. But they can be compared with the corresponding values calculated using the same method for "averaged" soil maps using the Monte Carlo method.

We generated 20,000 virtual soil maps, in which soils of classes from 0 to 4 occupy the same areas as those presented in Table 1 for a real soil map. However, the cells in these virtual maps were assigned different soil classes randomly. For each virtual map, the length of the boundary was calculated, and the result was averaged. We obtained the values $L_{R}=3101$ and $L_{R}=2104$ (before and after the virtual flooding). This allowed us to calculate the relative extent of the boundary ( $L / L_{R}$ ratio) before and after flooding: 0.62 and 0.55 , correspondingly. Interpretation of these results is quite simple: the smaller the relative extent of the boundary, the more heterogeneous is the distribution of soils on the site. In fact, on a real soil map, the areas occupied by soils of one class are grouped into 
clusters, as compared to random soil maps. And after flooding, this heterogeneity increases by $13 \%$ (if we consider it proportional to the change in the relative extent of the border).

\section{Results and discussion}

The obtained results can be interpreted as follows. After flooding, fire risks are reduced not only due to a significant (twice for the considered area) integral decrease in fire hazard of soils, but also due to the formation of a safer geometric configuration by fire-hazardous soils. We note that the fractal model of forest fires [16] shows that for an equal area of fires, those that have a longer fire front (in our case, this may be the boundary of fire-dangerous soils) are more dangerous. And the grouping of fire-hazardous soils also facilitates their monitoring and reduces the cost of fire-prevention measures.

Secondly, there are two main approaches to land use in the regions where wetland restoration is taking place. The first is the explicit allocation of lands subjected to flooding, which greatly changes the nature of land use (compared to what was before flooding). The second approach is to maintain the use of flooded land in the framework of the previous land use model, which can be appropriately modified to take into account changes in the ecosystem. Despite the fact that the second approach is considered more economical [17], in Ryazan Meshchera the modeling of land flooding, taking into account the decrease in fire danger, clearly shows the need for applying the first approach, since lands with different types of soils (and, consequently, with different ecosystems) will be grouped into separate clusters. The increasing large-scale heterogeneity of the soil cover after flooding makes it more preferable for those investment projects that are not targeted at integrated land use, but on a more narrowly specialized.

From Table 1 it follows that the total area of marsh lands grows by about one and a half times, while the area of agricultural land and forest land will decrease significantly. This will inevitably entail a decline in general economic rent. On the other hand, the growing area of bogs will allow extracting a large environmental rent associated with the absorption of carbon dioxide from the atmosphere, and the costs associated with the risk of fires should be significantly reduced. Thus, the restoration of wetlands carries both benefits and losses. To maximize the benefits, it is necessary to invest in a corresponding way in changing the nature of land use in the flooded lands.

\section{Conclusions}

1. In the restoration of wetlands, the investment risks associated with fires can be reduced by a factor of two by reducing the integral fire hazard of soils.

2. Strengthening large-scale heterogeneity in the distribution of soil types makes it more preferable not for complex but highly specialized land use.

3. The approach that we used for a certain land plot of the Ryazan Meshchera can be used for any other land plot located in the wetland restoration zone. Changes in the results will be quantitative, but qualitative changes are unlikely, if flooding is carried out on the same principle: soils of classes $0,1,2,3,4$ go to $0,1,1,2,3$ respectively.

\section{Acknowledgements}

The reported study was funded by RFBR according to the research project No. 17-1262002'Investment risks modeling in the course of changing the meliorative status of lands with firedangerous peatlands in Ryazan Meshchera".

\section{References}

[1] Joining forces with Russia on the wise use of wetlands. [online] [11.03.2018]. Available at: https://www.wetlands.org/news/joining-forces-russia-wise-use-wetlands/

[2] Saving Peat for Less Heat! An update. [online] [11.03.2018]. Available at: https://www.wetlands.org/publications/saving-peat-less-heat-update/

[3] Grand-Clement E. et al. Evaluating ecosystem goods and services after restoration of marginal upland peatlands in South-West England. Journal of Applied Ecology, 50, 2013, pp. 324-334.

[4] Ketcheson S. J., Price J. S..The Impact of Peatland Restoration on the Site Hydrology of an Abandoned Block-Cut Bog.Wetlands, v.31, 6, 2011, pp. 1263-1274. 
[5] Martin-Ortega J. et al. Valuing water quality improvements from peatland restoration: Evidence and challenges. Ecosystem Services, 9, 2014, pp. 34-43.

[6] Morris J. et al. Restoration of Lowland Peatland in England and Impacts on Food Production and Security. Report to Natural England. Cranfield University, Bedford, 2010.153 p.

[7] Peatlands - guidance for climate change mitigation through conservation, rehabilitation and sustainable use. Second edition.(MITIGATION OF CLIMATE CHANGE IN AGRICULTURE SERIES 5). H.Joosten, M.-L.Tapio-Biströmand Susanna Tol (eds.). Published by the Food and Agriculture Organization of the United Nations and Wetlands International. [online] [11.03.2018]. Available at: http://www.gret-perg.ulaval.ca/fileadmin/fichiers/fichiersGRET/pdf/Doc_generale/ Joosten_2012_Peatlands-guidance_for_climate_change.pdf

[8] Simila M., Aapala K., Penttinen J. Ecological Restoration in Drained Peatlands: Best Practices from Finland. Metsahallitus, Vantaa, 2014. 84 p.

[9] Vasander H. et al. Status and restoration of peatlands in northern Europe.Wetlands Ecology and Management, v.11, 1-2, 2003, pp. 51-63.

[10]MIKEFLOOD - моделирование карт затоплений (MIKEFLOOD - simulation of flooding maps). [online] [11.03.2018]. Available at: http://www.volgaltd.ru/rus/programs/ vodnyeresursy/mike-flood.html (In Russian)

[11]МажайскийЮ.А. и др. Использование ПК МIKЕ в процессе проектирования систем обводнения осушенных торфяников (Useof PCMIKE in the design of drainage systems of drained peatlands).Modern energy and resource-saving, environmentally sustainable technologies and agricultural production systems. Proceedings of the scientific conference. Volume 13. Ryazan: All-Russian research Institute of hydraulic engineering and land reclamation, 2017, pp. 48-51. Available at: https://elibrary.ru/item.asp?id = 32302558 (In Russian)

[12]Приказ Федерального агентства лесного хозяйства от 5 июля 2011 г. N 287 “Об утверждении классификации природной пожарной опасности лесов и классификации пожарной опасности в лесах в зависимости от условий погоды" (Order of the Federal Forestry Agency of July 5, 2011 No. 287 "On the approval of the classification of natural forest fire danger and classification of fire danger in forests depending on weather conditions") [online] [11.03.2018]. Available at: http://www.garant.ru/products/ipo/prime/doc/12089021/ (In Russian)

[13] Кривцов В. А. и др. Природный потенциал ландшафтов Рязанской области (Natural potential of landscapes of Ryazan region). Ryazan: Publishing house of Ryazan State Universitynamed for S.A. Yessenin, 2011. 768 p.(In Russian).

[14]ЗайдельманФ. Р. Генезис и экологические основы мелиорации почв и ландшафтов (Genesis and ecological bases of soil and landscape reclamation). Moscow: KDU, 2009. 720 p.(In Russian).

[15]ЗайдельманФ. Р. идр. Практикум по курсу «Мелиорацияпочв» (Workshoponthecourse "SoilMelioration"). Moscow: Publishing house of Moscow University, 2002, pp. 6-8. Available at:http://www.agriculture.uz/filesarchive/kursu_melioraciya_pochv.pdf (In Russian)

[16] Kudinov A. N., Tsvetkov V.P., Tsvetkov I.V. Fractal model of a forest fire. Software and Systems.2, 2010.pp.146-148. (In Russian).

[17] Chew Om. Conflicts and integration between wetlands and agriculture in Asia. International Journal of Ecology and Environmental Sciences.29, 2003, pp. 79-84. 